\title{
Composition and functionality of whey protein phospholipid concentrate and delactosed permeate
}

\author{
M. A. Levin, ${ }^{*}$ K. J. Burrington, $†$ and R. W. Hartel ${ }^{* 1}$ \\ *Department of Food Science, and \\ †Center for Dairy Research, University of Wisconsin-Madison, 1605 Linden Drive, Madison 53706-1565
}

\begin{abstract}
Whey protein phospholipid concentrate (WPPC) and delactosed permeate (DLP) are 2 coproducts of cheese whey processing that are currently underused. Past research has shown that WPPC and DLP can be used together as a functional dairy ingredient in foods such as ice cream, soup, and caramel. However, the scope of the research has been limited to 1 WPPC supplier. The objective of this research was to fully characterize a range of WPPC. Four WPPC samples and 1 DLP sample were analyzed for chemical composition and functionality. This analysis showed that WPPC composition was highly variable between suppliers and lots. In addition, the functionality of the WPPC varies depending on the supplier and testing $\mathrm{pH}$, and cannot be correlated with fat or protein content because of differences in processing. The addition of DLP to WPPC affects functionality. In general, WPPC has a high water-holding capacity, is relatively heat stable, has low foamability, and does not aid in emulsion stability. The gel strength and texture are highly dependent on the amount of protein. To be able to use these 2 dairy products, the composition and functionality must be fully understood.
\end{abstract}

Key words: whey protein phospholipid concentrate, delactosed permeate, whey functionality, whey composition

\section{INTRODUCTION}

Whey protein phospholipid concentrate (WPPC) and delactosed permeate (DLP) are products from the processing of cheese whey and are currently a disposal concern for the dairy industry. Whey protein phospholipid concentrate is a coproduct of whey protein isolate produced from the microfiltration of whey protein

Received February 1, 2016.

Accepted May 31, 2016.

${ }^{1}$ Corresponding author: rwhartel@wisc.edu concentrate (WPC), a process that separates the majority of the undenatured whey proteins from the fat, phospholipids, lactose, and denatured whey proteins. In 2015, the American Dairy Products Institute (2015) instituted a standard for WPPC composition: a minimum of $50 \%$ protein (dry basis), a minimum of $12 \%$ fat, a maximum of $8 \%$ ash, and a maximum of $6 \%$ moisture.

Whey protein phospholipid concentrate represents 14 to $18 \%$ of the total whey processed - approximately 32 million tonnes/year (Burrington, 2012). Delactosed permeate is produced in even greater quantities: $0.5 \mathrm{~kg}$ for every $1 \mathrm{~kg}$ of milk used in cheese production (Liang et al., 2009); DLP is an effluent of lactose crystallization from permeate and is high in lactose, organic acids, and minerals. Currently, only one ingredient manufacturer has commercialized a dry DLP and there exists no standard of identity. Both DLP and WPPC are currently underused in the food industry; they are primarily used for animal feed and spread on fields. If they could be used in value-added food applications, they would greatly benefit the dairy industry in terms of increased profitability and decreased disposal costs.

The composition, variability, and drying capabilities of DLP have been studied (Bund and Hartel, 2009; Liang et al., 2009). The addition of WPPC aids in the drying of DLP because of an increase in protein levels between 20 and 30\% (Bund and Hartel, 2009). Together, WPPC and DLP have been studied in food applications to replace emulsifiers, salt, eggs, and other dairy products in ice cream, soups, and confections (Burrington, 2011). However, the study of WPPC alone has been limited. Previous research has investigated how to prevent the fat in WPPC from oxidizing (Jensen at al., 2011) or how to incorporate WPPC into ice cream (Bund and Hartel, 2013; Daw and Hartel, 2015), but only one supplier of WPPC was used. The functionality and variability of WPPC has not yet been investigated.

Whey protein phospholipid concentrate is composed primarily of whey proteins and dairy lipids from the milk fat globule membrane. These 2 components have previously been shown to have functional properties. The phospholipids from the milk fat globule membrane 
have good emulsifying characteristics because of their polar and nonpolar composition. Whey proteins have strong gelling properties and high water-holding capacity, they are heat stable, and they form strong foams (Walstra et al., 2006). However, their functionality is highly dependent on the other components of the whey powders. For example, WPC with high protein content and high fat content will not foam because the fat disrupts the viscoelastic protein layer between the air and liquid.

The characteristics and composition of WPPC depend on both the starting whey and the process for whey protein separation. In this study, we investigated the variability of WPPC across several suppliers for both compositional and functionality differences. Additionally, we added dried DLP to the WPPC to examine its effect on functionality and to see if these 2 low-value dairy products could be combined.

\section{MATERIALS AND METHODS}

\section{Materials}

Several WPPC powders were obtained: Isocill 6000 from Agropur Ingredients (Lacrosse, WI), Perham $\mathrm{P}_{\mathrm{c}^{-}}$ Protein from Bongards Creameries (Minneapolis, MN), Whey Phospholipid Protein Concentrate from Milk Specialties Global (Eden Prairie, MN), and Whey Protein Concentrate High Fat from Leprino Foods (Denver, $\mathrm{CO}$ ). We obtained 2 batches from each supplier for this study, 6 mo apart. We obtained the only commercially dried DLP, Dairy Products Solid, from Leprino Foods.

\section{Compositional Analysis}

The total protein, fat, moisture, ash, lactose, and $\mathrm{pH}$ of the WPPC and DLP powders were determined according to standard AOAC methods (AOAC International, 2003) by the Center for Dairy Research (Madison, WI). The fatty acid composition and phospholipid composition of the WPPC powders were determined using standard GC methods (AOAC International, 2003) by POS-Bio Sciences (Saskatoon, SK, Canada).

\section{Microscopy}

All microscope images of WPPC samples were viewed using a Nikon Labphot-2 light microscope (Melville, NY) at $40 \times$ magnification. Images were recorded using a Qimagin QIcam camera (Surrey, BC, Canada) and analyzed using Image-Pro Plus software (Bethesda, MD). Two slides were prepared per sample, and 5 random images were taken per slide. To stain the protein, WPPC samples were hydrated in deionized water at $10 \%(\mathrm{wt} / \mathrm{vol}$ ) for $1 \mathrm{~h}$ at room temperature. The WPPC solutions were stained with $0.1 \%$ (wt/vol) eosin Y (Fisher Scientific, Waltham, MA) at 10\% (vol/ vol) concentration. Eosin $\mathrm{Y}$ is a dye that binds basic amino groups to result in a bright pink color (Lewis, 2007). To stain the phospholipids, the WPPC was mixed with $0.1 \%$ (vol/vol) luxol fast blue MBS solution (VWR International, Radnor, PA) at a 10\% (wt/vol) concentration and hydrated for $24 \mathrm{~h}$ at $65^{\circ} \mathrm{C}$. Luxol fast blue is a diarylguanidine salt of sulfonated copper phthalocyanine; through an acid-base reaction, it forms a blue complex with phospholipids (Salthouse, 1962).

\section{SDS-PAGE}

Sodium dodecyl sulfate-PAGE analysis was used to investigate the type of proteins and denatured proteins found in the WPPC. The WPPC samples were diluted to $1 \mathrm{mg} / \mathrm{mL}$ in solution with and without $\beta$-mercaptoethanol (Sigma-Aldrich, Saint Louis, MO). Pre-cast 4 to $20 \%$ Mini-Protean TGX gels with $1 \times$ Tris-Gly-SDS buffer (Sigma-Aldrich) were used for analysis; $25 \mu \mathrm{L}$ of sample was loaded into each lane and $5 \mu \mathrm{L}$ of SDS-PAGE broad-range protein standard (BioRad, Hercules, CA) was used as a molecular weight standard. Gels were run at $200 \mathrm{~V}$ for $30 \mathrm{~min}$ and stained with Coomassie blue (BioRad) (Shapiro et al., 1967).

\section{Functionality}

All samples of WPPC and blends with DLP were stored in an airtight, antihumidity chamber at $21^{\circ} \mathrm{C}$ to prevent moisture absorption. All functionality tests were performed at both native $\mathrm{pH}$ and $\mathrm{pH} 7$. All samples tested with $\mathrm{pH} 7$ were hydrated with $0.1 \mathrm{M}$ phosphate buffer ( $\mathrm{pH} 7$ ) and adjusted to the proper $\mathrm{pH}$ using $1 \mathrm{~N}$ $\mathrm{HCl}$ or $1 N \mathrm{NaOH}$. Only the second batch of WPPC samples was tested for functionality. The WPPC was blended with DLP at 3 ratios for the functionality tests: 0:100, 30:70, and 50:50 DLP:WPPC. All tests were performed in triplicate.

Water-Holding Capacity. Water-holding capacity (WHC) was determined at room temperature. The DLP:WPPC blends were hydrated at 10\% (wt/vol), mixed using Fisher Gene II Vortex in a preweighed 15$\mathrm{mL}$ centrifuge tube and allowed to incubate at room temperature for $1 \mathrm{~h}$. The samples were centrifuged at $2,000 \times g$ for $30 \mathrm{~min}$ in a Marathon $21 \mathrm{k} / \mathrm{R}$ centrifuge (Fisher Scientific). The supernatant was decanted into glass flasks and placed in a $100^{\circ} \mathrm{C}$ oven for $24 \mathrm{~h}$ to remove all water. The pellet and dry solids from the supernatant were weighed. Residual buffer or water in 
the tube and dry solids from the buffer were calculated by performing the experiment without the DLP:WPPC blends. We calculated WHC according to Equation [1] (Neumann et al., 1984):

$$
\begin{gathered}
\text { WHC }=[\text { wet pellet wt }(\mathrm{g}) \\
- \text { buffer retained by blank wt }(\mathrm{g})] / \\
{[\text { total sample wt }(\mathrm{g})-\text { decanted solids wt }(\mathrm{g})} \\
- \text { solids from buffer wt }(\mathrm{g})]
\end{gathered}
$$

Heat Stability Index. We hydrated the DLP:WPPC blends at $5 \%$ (wt/vol) for $1 \mathrm{~h}$ before testing. Then, 10 $\mathrm{mL}$ of solution was added to $15-\mathrm{mL}$ preweighed centrifuge tubes, weighed, heated in an $85^{\circ} \mathrm{C}$ water bath for $3 \mathrm{~min}$, and immediately cooled in an ice bath for $10 \mathrm{~min}$. The samples were centrifuged at 5,000 rpm for $15 \mathrm{~min}$ in a Marathon $21 \mathrm{k} / \mathrm{R}$ centrifuge (Fisher Scientific). The pellet was weighed, and the heat stability index (HSI) was calculated according to Equation [2] (Harper and Lee, 1998):

$$
\text { HSI }(\%)=\frac{\text { pellet } w t(g)}{10 \mathrm{~mL} \text { of solution } w t(g)} \times 100 \text {. }
$$

Foaming. Because DLP:WPPC blends do not exhibit high foamability or foam stability, they cannot be tested using the traditional overrun test. We used a test for short-life foams based on the Mosalux and Bikerman method (Iglesias et al., 1995; Coelho et al., 2011). First, $5 \%$ (wt/vol) DLP:WPPC blends were hydrated for $1 \mathrm{~h}$ before testing. Next, $10 \mathrm{~mL}$ of the mixture was poured into a glass tube $(2 \mathrm{~cm}$ diameter by $40 \mathrm{~cm}$ height) fitted with a glass frit filter. Air was bubbled into the mixture at a rate of $1 \mathrm{~L} / \mathrm{h}$ for $10 \mathrm{~min}$. The height of foam was measured to show foamability. Next, the air was turned off and the time until full foam collapse was measured to show the foam stability.

Emulsifying. Before testing, DLP:WPPC blends were hydrated at $2 \%(\mathrm{wt} / \mathrm{vol})$ for $1 \mathrm{~h}$. Emulsions were made by mixing $50 \mathrm{~mL}$ of WPPC solution and $25 \mathrm{~mL}$ of canola oil (Crisco; J. M. Smucker Company, Orrville, $\mathrm{OH})$. The solutions were homogenized for $3 \mathrm{~min}$ at speed 5 (10,000 rpm) with an Omni Mixer Homogenizer (Omni International, Kennesaw, GA).

To test the emulsifying capacity, $0.5 \mathrm{~mL}$ of the emulsion was mixed with $10 \mathrm{~mL}$ of $0.1 \%$ SDS and absorbance was measured at $500 \mathrm{~nm}$ in a Genesys 20 spectrophotometer (Fisher Scientific). A 0.1\% SDS solution was used to zero the spectrophotometer (Wu et al., 2009).

Emulsion stability was tested by placing $10 \mathrm{~mL}$ of the fresh emulsion in a sealed vial. The height of the emul- sion layer was measured at 0 and $24 \mathrm{~h}$. The percent change in height was reported as the emulsion stability (Wu et al., 2009).

Gelling. Gels were formed by first hydrating $20 \%$ (wt/vol) DLP:WPPC blends for $1 \mathrm{~h}$ at room temperature. To create a gel, $25 \mathrm{~mL}$ of solutions were heated from $25^{\circ} \mathrm{C}$ to $85^{\circ} \mathrm{C}$ at $5^{\circ} \mathrm{C} / \mathrm{min}$, held at $85^{\circ} \mathrm{C}$ for $10 \mathrm{~min}$, cooled to $25^{\circ} \mathrm{C}$ at $5^{\circ} \mathrm{C} / \mathrm{min}$, and held at $25^{\circ} \mathrm{C}$ for 10 min. Oscillatory rheological measurements during gel formation were made using a Discovery HR-2 hybrid rheometer (TA Instruments, New Castle, DE) with cupand-bob geometry, a frequency of $0.1 \mathrm{~Hz}$, and a shear strain of $1 \%$. The storage $\left(G^{\prime}\right)$ and loss $\left(G^{\prime \prime}\right)$ moduli were measured during gel formation. After the heating and cooling phase, a frequency sweep (100 to $0.1 \mathrm{~Hz}$ ) was performed. All results showed that the tests were within the viscoelastic region (Riou et al., 2011).

\section{Statistical Analysis}

All statistical analysis was performed in JMP Pro 11 (SAS Institute Inc., Cary, NC). The chemical composition data was analyzed using 1-way ANOVA and Tukey tests with $\alpha=0.05$. The functionality data was analyzed using 3-way ANOVA and Tukey tests with $\alpha$ $=0.05$.

\section{RESULTS AND DISCUSSION}

\section{Proximate Composition}

We analyzed WPPC samples for the main components. Two lots (1 and 2) were obtained from each of the 4 suppliers (A to D), 6 mo apart. We ran 2-way ANOVA for each component and found significant differences in the lots, WPPC type, and interaction between them in all composition categories $(P<0.01)$. A post hoc Tukey's test indicated the significant differences and can be seen in the connecting letters reported in Table 1.

All but one of the WPPC samples fit within the 2015 standard from the American Dairy Products Institute [minimum of $50 \%$ protein (dry basis), minimum of $12 \%$ fat, a maximum of $8 \%$ ash, and a maximum of $6 \%$ moisture); ADPI, 2015]. Lot 1 of supplier C had $10.85 \%$ fat, which fell slightly below the $12 \%$ limit. Even though the WPPC samples fell within the standard, there were still major differences in composition. We attributed these to 2 factors: differences in fat removal from the whey, leading to differences in whey protein concentrate composition, and differences in microfiltration system processing conditions. We observed the greatest differences in the fat and protein contents of each WPPC. 
Table 1. Proximate composition of 2 lots of whey protein phospholipid concentrates from each supplier $(\mathrm{n}=2$, means \pm SD)

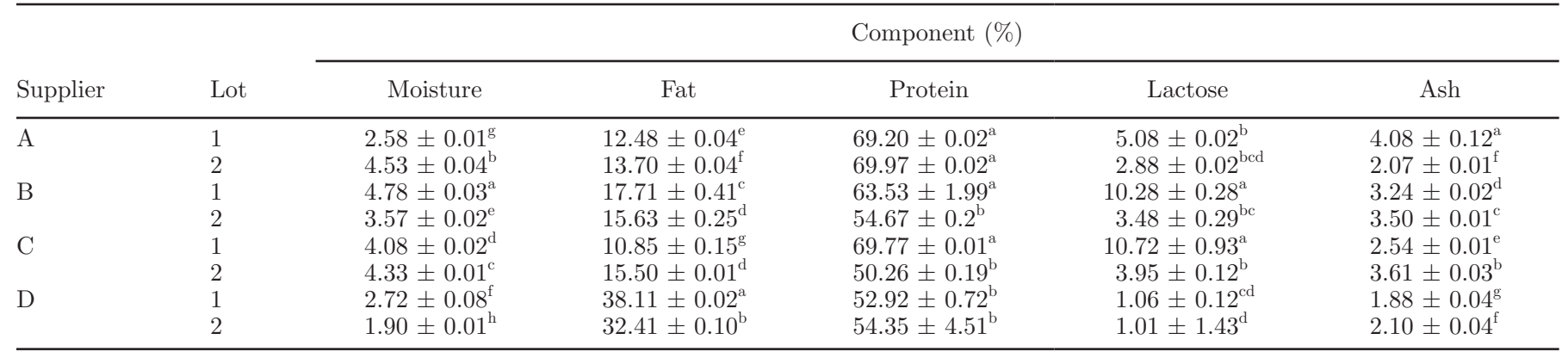

${ }^{\mathrm{a}-\mathrm{h}}$ Means within a column with different superscripts differ $(P<0.05)$.

For example, WPPC D had a significantly higher fat content, which could be attributed to higher fat content in the whey protein concentrate used to create the whey protein isolate. There is little standardization of WPPC composition because of its lack of value-added usage, so these differences were not surprising.

\section{pH}

The $\mathrm{pH}$ of mixtures of WPPC and DLP are reported in Table 2. We performed a 2-way ANOVA to determine the interaction between the type of WPPC and the addition level of DLP, and we found significant differences $(P<0.01)$. The $\mathrm{pH}$ of the DLP used in this study was 5.37. The $\mathrm{pH}$ of the pure WPPC solutions were significantly different and ranged from 5.10 to 6.46. These differences can be attributed to differences in ionic concentration and lactic acid concentration.

The type of whey (sweet or acid) used to produce the WPPC also influences the overall $\mathrm{pH}$, although no WPPC is currently made with acid whey (Sienkiewicz and Riedel, 1990). As DLP was incorporated into the solutions, the $\mathrm{pH}$ decreased, except in WPPC D, where the $\mathrm{pH}$ increased with addition of DLP. The changes in $\mathrm{pH}$ with DLP addition in WPPC A, B, and $\mathrm{C}$ were

Table 2. $\mathrm{pH}$ values of lot 2 of the $5 \%$ (wt/vol) solutions of whey protein phospholipid concentrate (WPPC) and delactosed permeate $(\mathrm{DLP}): \mathrm{WPPC}$ blends $(\mathrm{n}=2 \text {, means } \pm \mathrm{SD})^{1}$

\begin{tabular}{lccc}
\hline & \multicolumn{3}{c}{ DLP:WPPC ratio } \\
\cline { 2 - 4 } Supplier & $0: 100$ & $30: 70$ & $50: 50$ \\
\hline A & $6.12 \pm 0.01^{\mathrm{b}}$ & $6.00 \pm 0.01^{\mathrm{c}}$ & $5.82 \pm 0.03^{\mathrm{e}}$ \\
$\mathrm{B}$ & $6.46 \pm 0.01^{\mathrm{a}}$ & $5.98 \pm 0.01^{\mathrm{c}}$ & $5.78 \pm 0.02^{\mathrm{ef}}$ \\
C & $6.41 \pm 0.01^{\mathrm{a}}$ & $5.89 \pm 0.01^{\mathrm{d}}$ & $5.74 \pm 0.01^{\mathrm{f}}$ \\
$\mathrm{D}$ & $5.10 \pm 0.01^{\mathrm{i}}$ & $5.38 \pm 0.01^{\mathrm{h}}$ & $5.44 \pm 0.01^{\mathrm{g}}$ \\
\hline
\end{tabular}

${ }^{\mathrm{a}-\mathrm{i}}$ Means with different superscripts across all suppliers and blended ratios differ $(P<0.05)$. due to the differing buffering capacities of the salts and proteins.

\section{Protein Composition}

The relative compositions of the proteins in WPPC are shown in Figure 1. The SDS-PAGE results showed a high concentration of $\beta-\mathrm{LG}$ and $\alpha-\mathrm{LA}$, as well as the other serum proteins. Native proteins can be found in WPPC because filtration is not $100 \%$ efficient. Native proteins can be retained because of fouling or the use of a filter with a small pore size. Additionally, there were large amounts of aggregates, as shown by the comparison between the lanes treated and not treated with $\beta$-mercaptoethanol. The aggregates can also be seen in the microscope images in Figure 2. The proteins

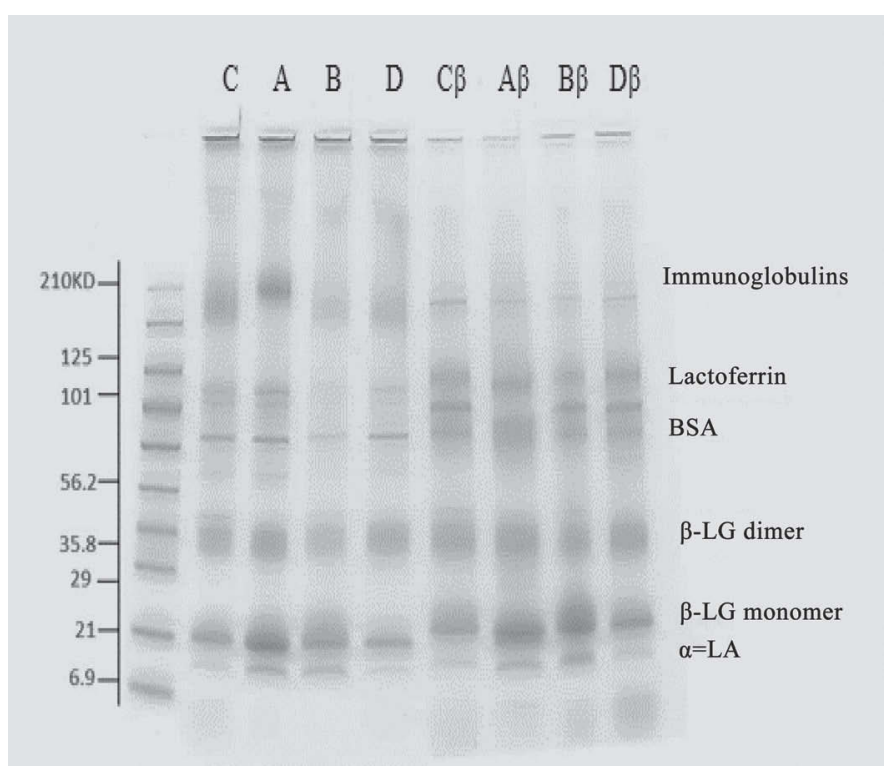

Figure 1. Sodium dodecyl sulfate-PAGE of whey protein phospholipid concentrate from 4 suppliers (A to $\mathrm{D})$ treated $(\mathrm{C} \beta, \mathrm{A} \beta, \mathrm{B} \beta, \mathrm{D} \beta)$ or not treated $(\mathrm{C}, \mathrm{A}, \mathrm{B}, \mathrm{D})$ with $\beta$-mercaptoethanol. 
Table 3. Fatty acid profile of average liquid bovine milk and whey protein phospholipid concentrate (WPPC) from 4 suppliers ${ }^{1}$

\begin{tabular}{|c|c|c|c|c|c|}
\hline \multirow[b]{2}{*}{$\begin{array}{l}\text { Fatty } \\
\text { acid }\end{array}$} & \multicolumn{5}{|c|}{ Product } \\
\hline & $\begin{array}{l}\text { Liquid } \\
\text { milk }\end{array}$ & $\begin{array}{c}\text { WPPC } \\
\text { A }\end{array}$ & $\begin{array}{c}\text { WPPC } \\
\text { B }\end{array}$ & $\begin{array}{c}\text { WPPC } \\
\mathrm{C}\end{array}$ & $\begin{array}{c}\text { WPPC } \\
\text { D }\end{array}$ \\
\hline $6: 0$ & 1.6 & 1.1 & 1.2 & 1.2 & 1.1 \\
\hline $8: 0$ & 1.3 & 0.9 & 1.00 & 1.0 & 0.9 \\
\hline 10:0 & 3.0 & 2.4 & 2.7 & 2.8 & 2.3 \\
\hline $12: 0$ & 3.1 & 3.2 & 3.5 & 3.7 & 3.1 \\
\hline 14:0 & 9.5 & 11.2 & 11.8 & 12.3 & 10.9 \\
\hline $16: 0$ & 26.3 & 31.3 & 32.9 & 33.9 & 32.0 \\
\hline $16: 1$ & 2.3 & 1.8 & 2.0 & 2.0 & 2.1 \\
\hline 18:0 & 14.6 & 12.7 & 11.0 & 10.3 & 11.6 \\
\hline $18: 1$ & 29.8 & 21.5 & 20.8 & 19.6 & 22.5 \\
\hline $18: 2$ & 2.4 & 2.9 & 2.4 & 2.6 & 2.4 \\
\hline $18: 3$ & 0.8 & 0.5 & 0.5 & 0.6 & 0.5 \\
\hline $20: 4$ & 1.0 & 0.1 & 0.1 & 0.1 & 0.1 \\
\hline
\end{tabular}

${ }^{1}$ All values are the percentage of the fatty acid in the total lipid content (wt/wt) (liquid milk data from Fox and McSweeney, 1997).

were dyed with eosin Y and appeared as masses under the microscope. The high concentration of protein aggregates can be attributed to the microfiltration of the whey protein concentrate.

\section{Lipid Composition}

The fatty acid compositions of batch 2 from the 4 suppliers of WPPC are reported in Table 3 and compared with the average fatty acid composition in liquid

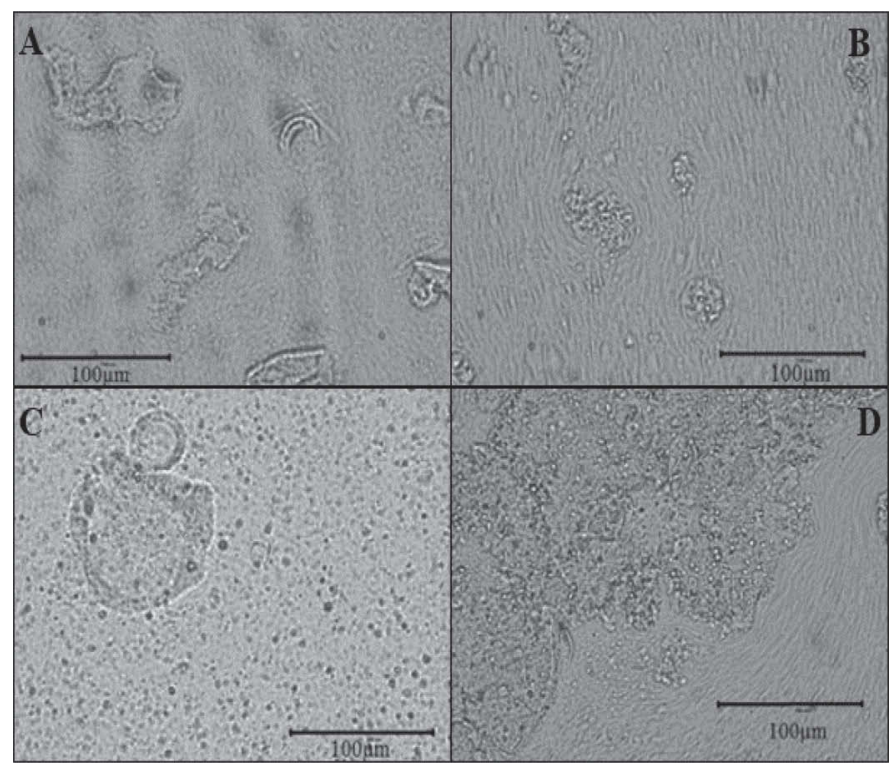

Figure 2. Whey protein phospholipid concentrate (from suppliers A to D) stained with eosin Y. The stained products appear in aggregates. The aggregates are larger in sample $\mathrm{C}$ and $\mathrm{D}$. milk. The WPPC samples showed similar fatty acid compositions, with the greatest range being 19.1 to $22.5 \%$ in oleic acid. The major fatty acids in milk were the same in WPPC: myristic, palmitic, stearic, and oleic. The fatty acid compositions were not identical to liquid milk because the majority of the triglycerides are removed through skimming, cheesemaking, and whey cream removal (Smit, 2003).

The free phospholipid composition for each WPPC can be found in Table 4. This analysis was done by fat extraction and GC analysis. The major phospholipids were phosphatidylcholine and phosphatidylethanolamine, which are also the major phospholipids in the milk fat globule membrane (Walstra et al., 2006). The total phospholipid content was lower than expected, because some companies advertise up to $20 \%$ phospholipids in their WPPC. As seen in Figure 3, the phospholipids appear to be bound to whey protein aggregates and cannot be quantified by testing free phospholipids. Phospholipids are dyed blue in the images.

\section{DLP Composition}

The composition of the dried DLP used in this study can be found in Table 5. This DLP is the only dried DLP currently on the market. Under polarized light microscopy, we found no crystallized lactose. We can infer that the lactose was in a glassy state and was not precrystallized before drying.

The solids composition of the dried DLP was different from that of the wet DLP used in previous studies but fell within the range of reported compositions ( $\mathrm{Li}-$ ang et al., 2009; Bund and Hartel, 2013). The DLP in this study had a high lactose and mineral content but a lower protein content. The composition of DLP from 
Table 4. Free phospholipid content (\%) of whey protein phospholipid concentrate ${ }^{1}$ from 4 suppliers

\begin{tabular}{lccc}
\hline Supplier & Phosphatidylethanolamine & Phosphatidylcholine & Total phospholipids \\
\hline A & 0.28 & 0.34 & 0.62 \\
B & 0.31 & 0.39 & 0.70 \\
C & 0.30 & 0.27 & 0.57 \\
D & 0.43 & 0.31 & 0.74 \\
\hline
\end{tabular}

${ }^{1}$ All values are reported as percent of the total fat content (wt/wt).

different suppliers varies due to the composition of the permeate, the lactose crystallization process, and the lack of a standard of identity.

\section{Functionality}

These experiments were performed to investigate the functionality of WPPC and blends of DLP:WPPC at 30:70 and 50:50. We used lot 2 from all 4 suppliers of WPPC. Tests were performed at the native $\mathrm{pH}$ and at $\mathrm{pH} 7$ to determine the potential effect on the functionality of the whey proteins.

Water-Holding Capacity. Water-holding capacity is a measurement of the grams of water that $1 \mathrm{~g}$ of powder can hold. It is measured by hydrating the powders, centrifuging the solution to remove the excess water, and then calculating the amount of water remaining in the solids. All results are shown in Figure 4. A 3-way ANOVA showed significant differences among the means $\left(F_{71,23}=49.30, P<0.01\right)$. All factors and interactions were significant except the interaction between the $\mathrm{pH}$ and blends.

Overall, the powders at $\mathrm{pH} 7$ held significantly less water than the powders at native $\mathrm{pH}$, with averages of 4.7 and $8.6 \mathrm{~g}$ of $\mathrm{H}_{2} \mathrm{O} / \mathrm{g}$, respectively. We also observed no difference in WHC at $\mathrm{pH} 7$ depending on WPPC or blend. This could be because the proteins have the same charge and therefore hold the same amount of water.

The addition of DLP to WPPC had a minimal effect on WHC. We observed no significant difference between WPPC and the 50:50 blends. The 30:70 blends had a slightly lower WHC $(P<0.01)$ but only by $0.5 \mathrm{~g}$, which was not a substantial amount. Delactosed permeate does not hold water, because it is not a hydrocolloid

Table 5. Proximate composition (\%) of dried delactosed permeate (DLP)

\begin{tabular}{lr}
\hline Component & Value \\
\hline Moisture & 2.37 \\
Fat & 0.21 \\
Protein & 0.66 \\
Lactose & 59.87 \\
Ash & 26.61 \\
\hline
\end{tabular}

or a protein. The lactose and minerals from the DLP are lost in the supernatant and are subtracted from the total solids, meaning that the test calculates the WHC of the proteins in the WPPC.

Sample WPPC D at native $\mathrm{pH}$ had the highest WHC, but it was only slightly higher than that of WPPC B. Samples WPPC A and C had significantly lower WHC; WPPC A had a higher percentage of total proteins than both D and B but held less water, potentially due to a lower amount of denatured protein. The WHC was primarily affected by the amount of denatured proteins, not the total amount of protein or fat. We observed no correlation between protein or moisture content. If a protein is unfolded, the hydrophilic amino acids are exposed and will hold more water. The WHC can also be influenced by processing, with higher heat treatments leading to increased protein denaturation (and higher WHC).

Heat Stability Index. The HSI is a measure of how much of a powder will precipitate after temperature abuse. Solutions of WPPC and DLP:WPPC blends

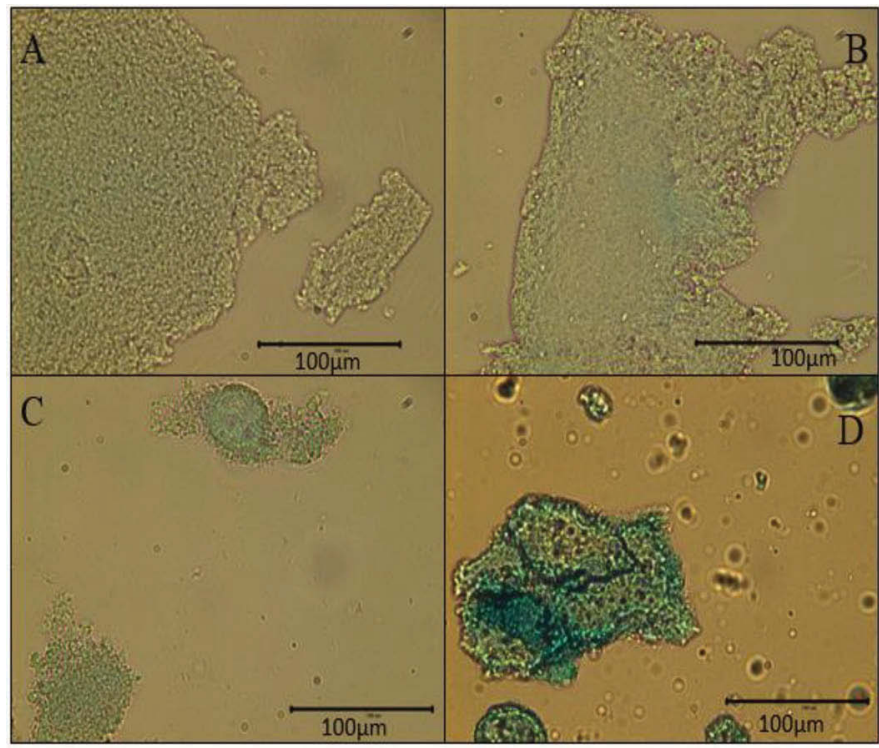

Figure 3. Whey protein phospholipid concentrate (from suppliers A to D) dyed with luxol fast blue. The phospholipids are dyed blue. The blue masses indicate that the phospholipids are bound to the protein aggregates. Color version available online. 


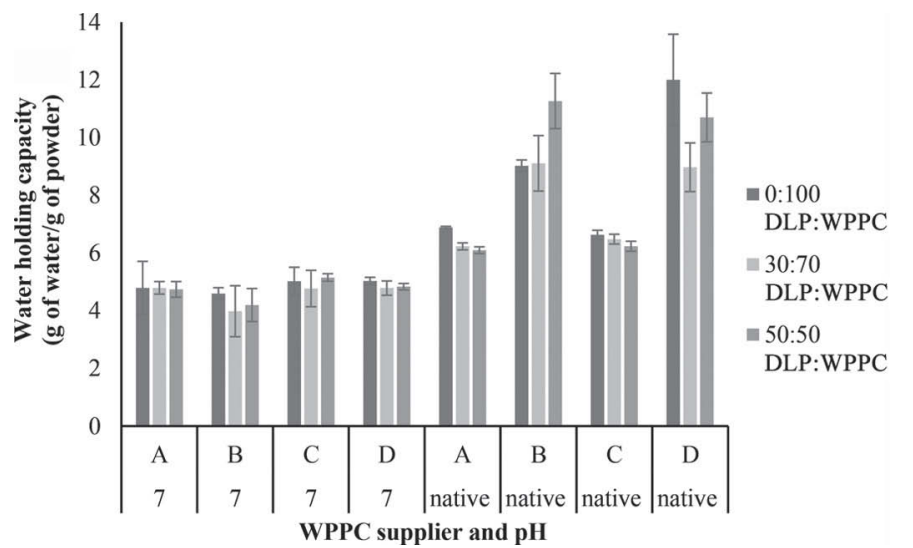

Figure 4. Water-holding capacity (grams of water retained in the sediment) for delactosed permeate (DLP) and whey protein phospholipid concentrate (WPPC) blends from 4 suppliers (A to D) at 2 different $\mathrm{pH}$ ( $\mathrm{pH} 7$ and native). Error bars represent one standard deviation $(\mathrm{n}=3)$.

were heated to $85^{\circ} \mathrm{C}$, immediately cooled in an ice bath, and returned to room temperature. The amount of powder remaining in solution after temperature abuse and centrifugation was measured and reported as the HSI; results are shown in Figure 5. Whey proteins are water soluble and remain in solution even when denatured; therefore, it was expected that WPPC would be relatively heat stable (Walstra et al., 2006). A 3-way ANOVA showed significant differences among the means of HSI and all factors, and interactions were significant $\left(F_{71,23}=56.68, P<0.01\right)$. The HSI at $\mathrm{pH}$ 7 was significantly higher than at the native $\mathrm{pH}$, but we observed an average difference of only $1.7 \%$ of the amount of powder remaining in solution.

As the DLP content increased in the blends, the HSI also increased. Only the proteins precipitate with heat; therefore, as the protein content decreases, so does powder precipitation. Lactose, minerals, and fat are not subject to temperature abuse. The majority of DLP components, lactose and ash, remain soluble in solution unless cooled to low temperatures. In this test, the solution was brought back to room temperature; thus, any lactose or minerals that crystallized during the cooling process would dissolve and not be present in the precipitate.

Samples WPPC C and B had the highest HSI and were not significantly different from each other. Sample WPPC A had a significantly lower HSI, which could be attributed to its higher protein content. With more protein, more material can precipitate as a result of temperature abuse. However, differences in HSI could not be attributed only to protein content, because the HSI and protein content were not linearly correlated. Sample WPPC D had the lowest HSI and the highest

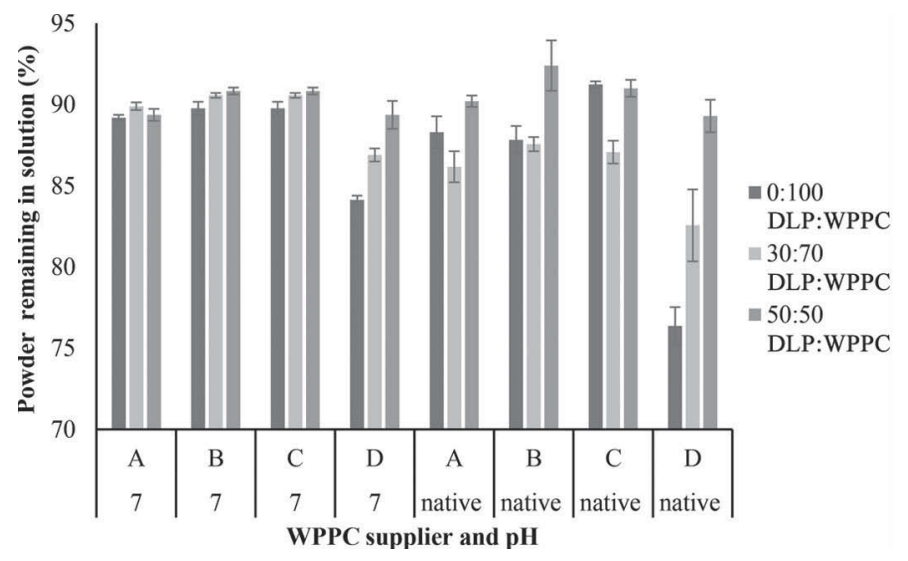

Figure 5. Heat stability index for delactosed permeate (DLP) and whey protein phospholipid concentrate (WPPC) blends from 4 suppliers (A to D) at 2 different $\mathrm{pH}$ ( $\mathrm{pH} 7$ and native). Error bars represent one standard deviation $(\mathrm{n}=3)$.

fat content. The solubility of WPPC D powder could be lower, because even though it had a protein content similar to that of $\mathrm{B}$ and $\mathrm{C}$, it had more insoluble components. Further investigation into WPPC powder solubility is needed to confirm that fat content does not cause WPPC to be less soluble.

Foaming. Traditionally, protein foaming is measured by an overrun test, which quantifies the amount of air held in the foam by measuring the volume of the foam and the volume of the initial solution. Whey proteins are known to have high foamability because the proteins form a strong adsorbed layer at the airwater interface. However, whey protein powders high in residual lipids are known to lack foaming functionality. In the presence of fats, the strength of the adsorbed

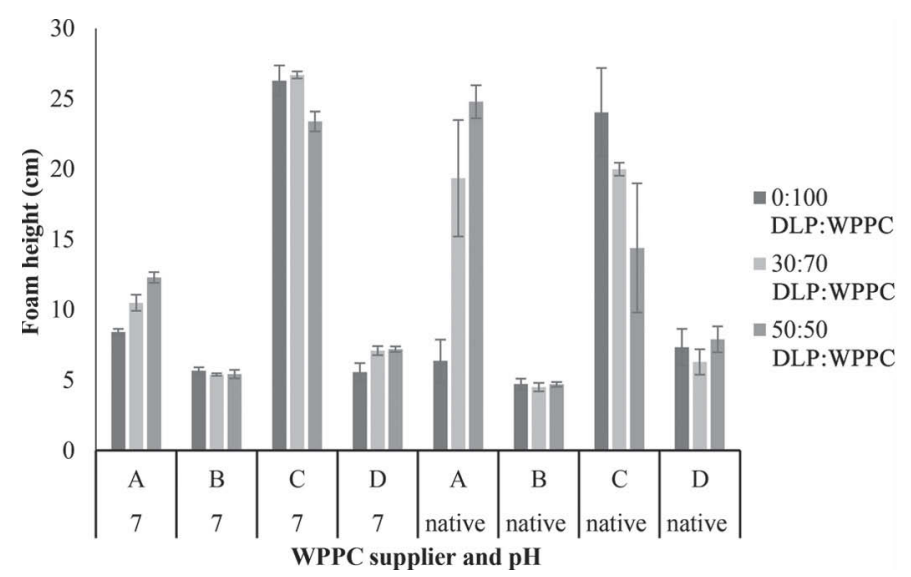

Figure 6. Foam height $(\mathrm{cm})$ for delactosed permeate (DLP) and whey protein phospholipid concentrate (WPPC) blends from 4 suppliers (A to D) at 2 different $\mathrm{pH}$ ( $\mathrm{pH} 7$ and native). Error bars represent one standard deviation $(\mathrm{n}=3)$. 
protein layer is much weaker because the lipids adsorb alongside the proteins and reduce the protein-protein interactions (Blecker et al., 1997).

Due to the low foamability, we used an alternate test based on the Mosalux and Bikerman method for low foaming solutions (Iglesias et al., 1995; Coelho et al., 2011). Air was constantly bubbled through a solution of WPPC or DLP:WPPC for $10 \mathrm{~min}$, and then the maximum height of the foam was recorded, as shown in Figure 6. Next, the air stream was turned off and the time for all of the bubbles to collapse was recorded, as shown in Figure 7.

The foam height was highly dependent on the type of WPPC. A 3-way ANOVA showed significant differences among the means $\left(F_{71,23}=77.32, P<0.01\right)$. All factors and interactions were significant except for $\mathrm{pH}$ and the interaction between $\mathrm{pH}$ and the blends. The addition of DLP to the WPPC caused significantly higher foam than for the individual WPPC, except for WPPC C. However, the average difference was only $1.3 \mathrm{~cm}$, and results were highly variable across WPPC samples. Because DLP has nothing in its composition that aids foamability, the inability of WPPC to foam may be improved by the addition of DLP because it dilutes the components of WPPC.

The type of WPPC had the greatest influence on foamability, with significant differences among them. Sample WPPC C had the highest foamability, followed by A, B, and D. Samples WPPC B and D had the lowest foamability, with hardly any increase in height during the $10 \mathrm{~min}$ of air inclusion. These differences could be due to the amount of denatured protein, the amount of whey-fat complexes, and the amount of free fat. However, neither fat nor protein content could be directly correlated to foam height.

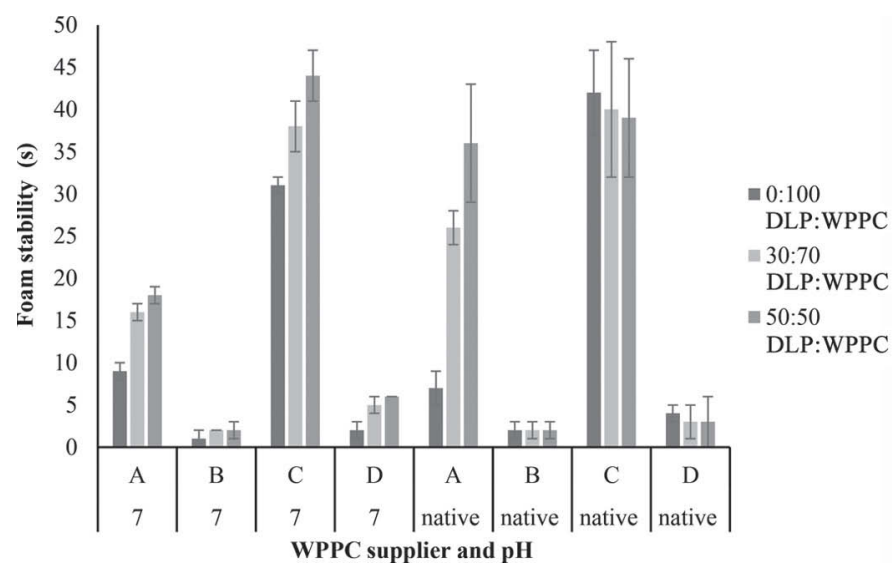

Figure 7. Foam stability (time for foam to dissipate; s) for delactosed permeate (DLP) and whey protein phospholipid concentrate (WPPC) blends from 4 suppliers (A to D) at 2 different $\mathrm{pH}$ ( $\mathrm{pH} 7$ and native). Error bars represent one standard deviation $(\mathrm{n}=3)$.
Foam stability is the time required for all of the bubbles to pop and the foam to collapse; results are shown in Figure 7. Foam stability can be directly correlated to foam height. If there are more bubbles to start with, it will take longer for them to collapse. In keeping with the lack of foamability, none of the samples produced foams that maintained any bubbles for more than 1 min. A 3-way ANOVA showed significant differences among the means $\left(F_{71,23}=85.09, P<0.01\right)$. All variables and interactions were seen as significant except the interaction between the $\mathrm{pH}$ and blends. Sample WPPC C exhibited the most foam stability, with an average of $39 \mathrm{~s}$; sample WPPC A collapsed in half that time, and samples WPPC D and B showed no significant differences at 4 and $2 \mathrm{~s}$, respectively.

Overall, WPPC at native $\mathrm{pH}$ had significantly higher foam stability than $\mathrm{pH} 7$, but we observed significant differences only in foams made with WPPC B and D. An increase in DLP led to an increase in foam stability. In whey protein concentrate, an increase in ash content and a decrease of fat content have been correlated with increased foam stability, which was seen in the blends of DLP:WPPC (Peltonen-Shalaby and Mangino, 1986). Foam stability cannot be directly correlated to fat and protein content, and it is more dependent on the native and denatured protein and the fat-protein interactions, because whey proteins are bound to phospholipids, which reduces foaming.

Emulsifying. Emulsions, similar to foams, are stabilized when proteins or surfactants form a viscoelastic layer between the oil and water interface. Residual lipids can weaken this layer by weakening the proteinprotein interactions (Blecker et al., 1997). Phospholipids are commonly added to emulsions to prevent fat from coalescing, but they are added in purified form, not bound to whey proteins. When surfactants and proteins are both present in an emulsion, the small molecular weight surfactants displace the proteins at the oil-water interface (Damodaran et al., 2008).

Emulsions were measured in 2 ways in this study: emulsion capacity and emulsion stability. Emulsion capacity tests how much oil can be added to an oilin-water emulsion before the phases are inverted. It is measured by testing the absorbance of the emulsion at $500 \mathrm{~nm}$; a higher absorbance value indicates that a higher percentage of oil can be added. Emulsion stability shows how much oil will cream off after $24 \mathrm{~h}$. It is measured by measuring the height of the cream layer and comparing it with the height of the initial emulsion.

Emulsion capacity results are shown in Figure 8. A 3 -way ANOVA showed significant differences among the means $\left(F_{71.23}=1,108.41, P<0.01\right)$. All variables and interactions were significant; adding DLP to WPPC caused significant differences. As the concentration of 
DLP increased, the emulsion capacity decreased, due to lower levels of protein and phospholipids with higher DLP levels. The components of DLP-lactose and minerals - cannot go to the interface. Therefore, with fewer molecules to aid in emulsification, less oil could be added to the emulsion before phase inversion.

Emulsions at $\mathrm{pH} 7$ had a significantly lower emulsion capacity than those at native $\mathrm{pH}$. Even the emulsions with the highest amounts of DLP and native $\mathrm{pH}$ showed higher emulsion capacity than all of the emulsions at $\mathrm{pH}$ 7. This finding could be attributed to the charge of the proteins at the different $\mathrm{pH}$. At $\mathrm{pH} 7, \beta$-LG has an increased negative charge compared with that at the native $\mathrm{pH}$ of 5.10 to 6.12 (Burrington, 2012). It will associate more with water and less with oil, causing a decrease in the volume of oil that can be incorporated before phase inversion.

The different types of WPPC had significant differences in emulsion capacity. For example, WPPC D and A exhibited the highest emulsion capacities and were not significantly different from each other. Sample A had the highest protein content and sample D had the highest fat content, both of which work to increase emulsion capacity. Sample C showed significantly lower emulsion capacity, and sample B was the lowest. The latter 2 WPPC had lower protein and lower fat contents. However, emulsion capacity could not be directly correlated to protein or fat content.

The emulsion stability results are shown in Figure 9. A 3-way ANOVA showed significant differences among the means $\left(F_{71,23}=11.34, P<0.01\right)$. The $\mathrm{pH}$ and DLP content did not cause significant differences in emulsion stability. All interactions and WPPC type were significant. However, variations between WPPC

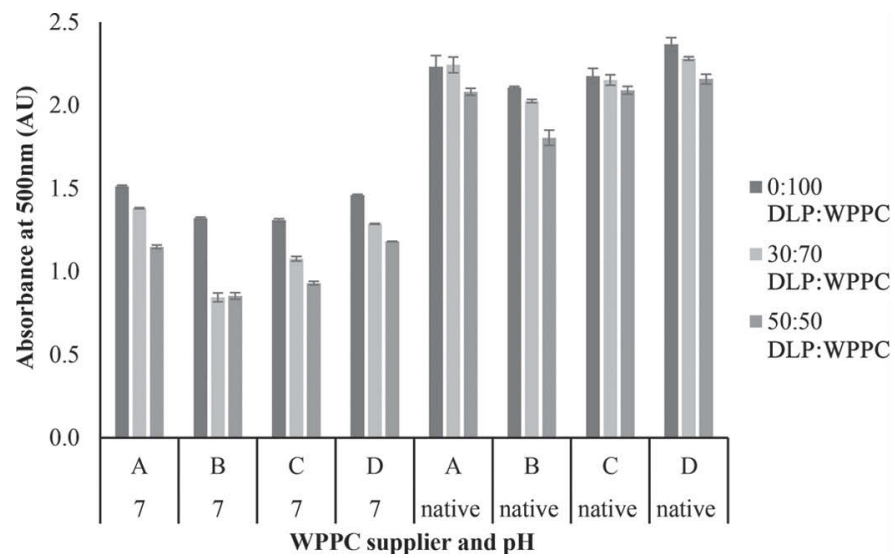

Figure 8. Emulsion capacity (absorbance at $500 \mathrm{~nm}$, arbitrary units, AU) for delactosed permeate (DLP) and whey protein phospholipid concentrate (WPPC) blends from 4 suppliers (A to D) at 2 different $\mathrm{pH}(\mathrm{pH} 7$ and native). Error bars represent one standard deviation $(\mathrm{n}=3)$.

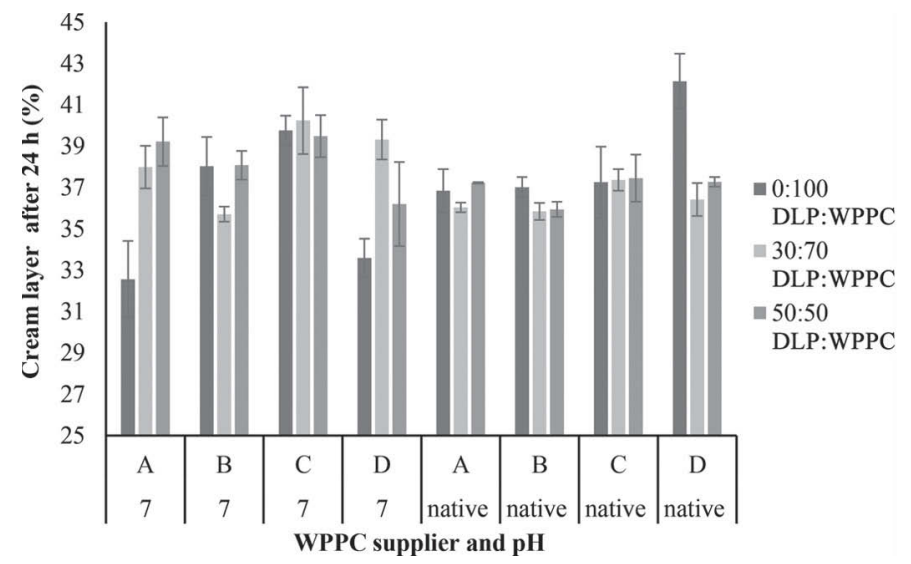

Figure 9. Emulsion stability (\% of cream layer after $24 \mathrm{~h}$ ) for delactosed permeate (DLP) and whey protein phospholipid concentrate (WPPC) blends from 4 suppliers (A to D) at 2 different $\mathrm{pH}$ ( $\mathrm{pH} 7$ and native). Error bars represent one standard deviation $(\mathrm{n}=3)$.

types were inconsistent and sometimes contradictory. Overall, WPPC C showed the highest amount of separation but with only $1.8 \%$ increase in the height of the cream layer. We observed no clear trend for the effects of $\mathrm{pH}$, DLP content, or WPPC type. Overall, all emulsions completely separated. Further, because the initial emulsions were $33 \%$ oil and all emulsions after $24 \mathrm{~h}$ had more than $33 \%$ cream layer, a portion of the WPPC remained in the cream layer. No correlations were found to fat or protein content.

Gelling. Whey proteins form a heat-set gel when heated above the denaturation temperature $\left(70^{\circ} \mathrm{C}\right)$ and increase in firmness when cooled. The gels are formed when the proteins denature and form aggregate networks (Damodaran et al., 2008). Components such as fat, lactose, and minerals disrupt these aggregate networks by interfering with the protein interactions.

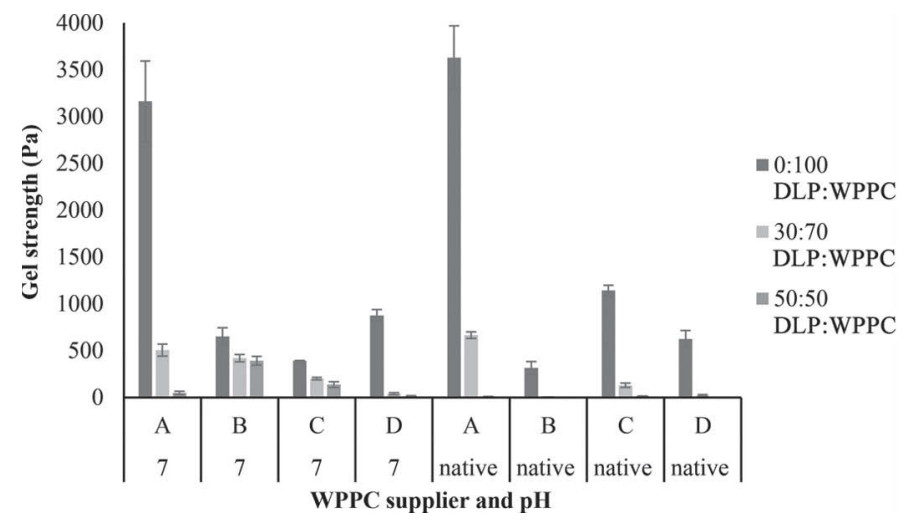

Figure 10. Gel strength (maximum $\mathrm{Pa}$ ) for delactosed permeate (DLP) and whey protein phospholipid concentrate (WPPC) blends from 4 suppliers (A to D) at 2 different $\mathrm{pH}$ ( $\mathrm{pH} 7$ and native). Error bars represent one standard deviation $(\mathrm{n}=3)$. 
The strength of these networks can be measured by using rheology. Solutions of WPPC and DLP:WPPC were heated to $85^{\circ} \mathrm{C}$ at $5^{\circ} \mathrm{C} / \mathrm{min}$, maintained at $85^{\circ} \mathrm{C}$ for $10 \mathrm{~min}$, and cooled to $25^{\circ} \mathrm{C}$ at $5^{\circ} \mathrm{C} / \mathrm{min}$. The maximum storage modulus $(\mathrm{Pa})$ when the gels were cooled was recorded as the gel strength. Results are shown in Figure 10.

A 3-way ANOVA showed significant differences among the means for gel strength $\left(F_{71,23}=83.40, P<0.01\right)$. All variables and interactions were significant except $\mathrm{pH}$. The $\mathrm{pH}$ was not significant due to the overarching effect of the protein content. Sample A exhibited 4 times the gel strength of the other WPPC, none of which was significantly different from the other. Sample A had significantly more protein than the other WPPC and most likely had less denatured protein. Because the protein is denatured by heat, it forms bonds with the other proteins instead of other components, causing a strong gel to be formed. The other WPPC had more denatured protein bonded to the phospholipids and could not form strong protein-protein interactions. Additionally, WPPC A had the lowest percentage of fat and minerals, which can interfere with gel structure.

The observed textures of the gels were greatly different. Sample A formed a gel that was similar to cream cheese, and the others formed gels similar to thick pudding and had little stand-up properties.

The addition of DLP significantly reduced the gel strength and destroyed the gels with $50 \%$ replacement at the native $\mathrm{pH}$. The DLP adds filler molecules (lactose and minerals) that weaken or disrupt the protein interactions. Additionally, as the DLP replaces the WPPC, less protein is available to form interactions, so a weaker gel is formed. The protein content significantly affected the gel strength and followed the power law, with exponent values falling between the typical values of 2 and 8 (Ikeda et al., 1999). Similar results have been seen in previous research: as the concentration of whey proteins increases, protein interactions also increase in the form of disulfide bonds, increasing gel strength (Langley et al., 1986).

\section{CONCLUSIONS}

Whey protein phospholipid concentrate is a coproduct of whey protein isolate, produced from the microfiltration of WPC. It is composed of whey proteins ( $\sim 50-70 \%)$, lipids $(\sim 10-40 \%)$, and lactose $(\sim 1-11 \%)$. The whey proteins are in both the native and denatured state, and the phospholipids are primarily associated with the denatured proteins. We found significant variability in composition between WPPC suppliers and lots, a result that can be attributed to differences in starting whey composition and processing param- eters, because there is no standard of identity. The functionality of the WPPC evaluated in this study was not consistent between suppliers, could not be directly correlated to the total protein or fat content, and was sometimes different when the $\mathrm{pH}$ was altered. This means that functionality may be influenced by factors that were not measured in this study, including processing conditions and the amount of denatured protein. In general, the WPPC samples and DLP:WPPC blends had high WHC and high HSI. The foaming ability and stability of WPPC were low due to the high amount of lipids. The emulsion capacity of WPPC was generally high, but the emulsions showed no stability. When DLP was added to WPPC, the emulsion capacity was significantly lower, but emulsion stability was not affected due to the complete separation of the oil and water phases, both with and without DLP addition. Finally, gel strength was significantly higher in one sample due to the high amount of protein. As DLP was added, the gel strength of all WPPC decreased and, with high levels of DLP, no gels were formed.

\section{ACKNOWLEDGMENTS}

We acknowledge the National Dairy Council (Rosemont, IL) for funding this work.

\section{REFERENCES}

American Dairy Products Institute (ADPI). 2015. Whey protein phospholipids concentrate standard. Accessed Nov. 4, 2015. https://www.adpi.org/Portals/0/Standards/WPPC\% 20 standard\%20final\%208-10-15.pdf

AOAC International. 2003. Official Methods of Analysis. 17th ed. AOAC International, Gaithersburg, MD.

Blecker, C., M. Paquot, I. Lamberti, A. Sensidoni, G. Lognay, and C. Deroanne. 1997. Improved emulsifying and foaming of whey proteins after enzymic fat hydrolysis. J. Food Sci. 62:48-52.

Bund, R. K., and R. W. Hartel. 2009. Effect of protein on sorption characteristics of delactosed permeate. J. Food Eng. 96:388-393.

Bund, R. K., and R. W. Hartel. 2013. Blends of delactosed permeate and pro-cream in ice cream: effects on physical, textural and sensory attributes. Int. Dairy J. 31:132-138.

Burrington, K. J. 2011. Applications monograph: Permeate for sodium reduction. Accessed May 4, 2015. http://www.usdairy.com/ / media/usd/public/coproducts_milk_report.pdf.

Burrington, K. J. 2012. Whey protein heat stability. Accessed May 4, 2015. http://www.usdairy.com/ /media/usd/public/ technicalreportwheyproteinheatstability.pdf.

Coelho, E., S. M. Rocha, and M. A. Coimbra. 2011. Foamability and foam stability of molecular reconstituted model sparkling wines. J. Agric. Food Chem. 59:8770-8778.

Damodaran, S., K. L. Parkin, and O. R. Fennema. 2008. Food Chemistry. 4th ed. CRC/Taylor \& Francis, Boca Raton, FL.

Daw, E., and R. Hartel. 2015. Fat destabilization and melt-down of ice creams with increased protein content. Int. Dairy J. 43:33-41.

Fox, P. F., and P. L. H. McSweeney. 1997. Dairy Chemistry and Biochemistry. Blackie Academic \& Professional, London, UK.

Harper, W. J., and K. Lee. 1998. Functional properties of 34\% whey protein concentrates. Pages 140-153 in Proc. Int. Dairy Fed. International Dairy Federation, Chicago, IL. 
Iglesias, E., J. Anderez, A. Forgiarini, and J. Salager. 1995. A new method to estimate the stability of short-life foams. Colloid Surfaces A: Physicochem. Eng. Aspects 98:167-174.

Ikeda, S., E. A. Foegeding, and T. Hagiwara. 1999. Rheological study on the fractal nature of the protein gel structure. Langmuir $15: 8584-8589$

Jensen, B. M., J. H. Nielsen, J. Sørensen, G. Mortensen, and T. K. Dalsgaard. 2011. Changing oxidation in whey fat concentrate upon addition of green tea extract. Eur. Food Res. Technol. 233:631-636.

Langley, K. R., D. Millard, and E. W. Evans. 1986. Determination of tensile strength of gels prepared from fractionated whey proteins. J. Dairy Res. 53:285-292.

Lewis, D. F. 2007. Microstructure of frozen and dairy-based confectionery products. Pages 236-257 in Structure of Dairy Products. Blackwell Pub., Oxford, UK.

Liang, B., R. K. Bund, and R. W. Hartel. 2009. Effect of composition on moisture sorption of delactosed permeate. Int. Dairy J. 19:630-636

Neumann, P. E., B. K. Jasberg, and J. S. Wall. 1984. Uniquely textured products obtained by coextrusion of corn gluten meal and soy flour. Cereal Chem. 61:439-445.

Peltonen-Shalaby, R., and M. E. Mangino. 1986. Compositional factors that affect the emulsifying and foaming properties of whey protein concentrates. J. Food Sci. 51:91-95.
Riou, E., P. Havea, O. Mccarthy, P. Watkinson, and H. Singh. 2011. Behavior of protein in the presence of calcium during heating of whey protein concentrate solutions. J. Agric. Food Chem. 59:13156-13164.

Salthouse, T. N. 1962. Reversal of solubility characteristics of 'Luxol' dye-phospholipid complexes. Nature 195:187-188.

Shapiro, A. L., E. Viñuela, and J. V. Maizel. 1967. Molecular weight estimation of polypeptide chains by electrophoresis in SDS-polyacrylamide gels. Biochem. Biophys. Res. Commun. 28:815-820.

Sienkiewicz, T., and C. L. Riedel. 1990. Whey and Whey Utilization Possibilities for Utilization in Agriculture and Foodstuffs Production. Mann Publisher, Gelsenkirchen-Buer, Germany.

Smit, G. 2003. Dairy Processing: Improving Quality. Woodhead Ltd., Cambridge, UK.

Walstra, P., J. T. M. Wouters, and T. J. Geurts. 2006. Dairy Science and Technology. CRC/Taylor \& Francis, New York, NY.

Wu, H., Q. Wang, T. Ma, and J. Ren. 2009. Comparative studies on the functional properties of various protein concentrate preparations of peanut protein. Food Res. Int. 42:343-348. 